\title{
The Problems of Overuse of Electronic Games in Smart Devices from the Parents' Perspective: A Study Applied to a Sample of Parents in the Gaza Strip
}

\author{
Amjad Almofty \\ Islamic University of Gaza, Palestine \\ Email: amofty [AT] iugaza.edu.ps
}

\begin{abstract}
The study aims to identify the problems arising from the children's overuse of electronic games with smart devices from parents' perspective. The study used the method of social survey sample through an electronic questionnaire applied by (312) parents in the time period 2/4 to 7/5/2020. The study found that there are problems resulting from the excessive use of electronic games by smart devices where the family problems came first and then behavioral problems, health problems and finally the study problems with an average level for all. Also, the study found statistical differences between the overuse of children on electronic games and variables attributable to the type of child and the type of games used and the duration of the play. The study recommended some recommendations including the selection of the parents of the appropriate games for the age and sex of the child, putting a time period for play, the family availing social, sports, and scientific, cultural recreational activities for the children to mitigate the overuse of children of electronic games.
\end{abstract}

Keywords---- Overuse , Children , Electronic Games , Smart Devices

\section{INTRODUCTION}

Play is the finest means of expression in children's lives, the play molds their world of all its experiences which leads to the development of all aspects of development, including cognitive, emotional and social development, and play is a manifestation of human behavior in early childhood, which is the stage of putting the first building blocks in the formation of an individual's personality (Ibrahim, 2019).

With the development and tremendous technical and electronic progress in all fields, the methods of play and entertainment have also evolved, where traditional toys no longer attract the attention of children, but the children of this generation are attracted to other types of games as a result of the spread of smart devices and internet games, where these games have the element of thrill and adventure which touches the needs of children at this stage.

One of the most common of these games in this era is known as electronic games, it has spread widely and found a popular market because of its attractiveness, drawings, colors, imagination and adventure, which made it capture the minds and interests of children and became their main concern, as it is hardly without a home, but has become an integral part of the children's room (Abd al-Sayed, 2019).

Electronic games are known as electronic entertainment and amusement games, and they are also an activity in which players engage in a contrived conflict governed by certain rules (Atiyah, 2019).

The researcher defines it in this study as: the group of games played by children aged 4-12 years and available on mobile phones and electronic tablets, represented by combat games, competitions, adventures and games of intelligence.

Children's use of touchscreen games has recently been frequent, whether on electronic tablets or mobile smart devices (Mitwali, 2017).

Smart devices are known as portable wireless communication devices such as phones and digital tablets with internetconnected services and applications, including iPads, iPhone and modern phones that can be carried and moved with (Jafar, 2017). 
Smart devices are defined as a device that can make and receive phone calls, taking advantage of internet connectivity, and can roam through wide geographical locations, and does so by connecting to a cellular network belonging to a telephone service provider, and allowing access to a public telephone network (Hamshari, 2019).

Where there are many elements in the games of these devices that make them beloved for children and their objectives are clear where most of the games depend on achieving a specific goal and clear, and the level of progression in them is reasonable as most of the games contain several levels of difficulty commensurate with different ages and challenging them, as well characterized by the several levels of speed, many electronic games are characterized by high degrees of speed leading to the challenge of the skills of the player (Moawad, 2016).

Despite the benefits that may be included in some electronic games, they have more negative effects than their pros, because of the risks and health, family and behavioral risks and problems that should be addressed and the child's awareness about their negative effects.

Since excessive use of these games by children negatively affects their health whereas spending long hours in front of the games causes pain in the head, neck and back and in general problems resulting from the conditions of the body and skeleton, as well as the problems resulting from the long view of the screen and its close proximity to the muscles of the eye and nerves that lead to redness of the eye and the feeling of itching (Ibn al-Hadlaq, 2013).

It also negatively affects the child's behavioral aspects with psychological manifestations such as fear and phobia, disturbed sleep, low self-confidence, anxiety, aggressive behavior, hatred of others, distraction, poor thinking, introversion, confusion between reality and imagination. (Abdul Aziz, 2011).

Also, the child becomes stuck to the smartphone and hardly leaves it, which leads to the transformation of the child into an a stranger in his/her family, introverted and busy looking at a smartphone and thus away from family and real friends, leading to harm of family ties (Dabous, 2018).

Many studies and scientific research have confirmed these problems and risks resulting from the overuse of electronic games by children, where (Mohammed, 2019) carried out a study to develop proposed mechanisms to enhance the competitiveness of the educational media industry to face the dangers of children's addiction to globalized recreational electronic games, and concluded that there are many reasons that helped the spread of electronic games, the most important of which is the ease of use by children, as came combat games, and racing games are at the forefront of the most important forms of electronic games practiced by children.

The study of (al-Tawer, 2018) also aimed to find out the change in the role of online games from creativity and innovation to a tool for suicide, and found that internet games have shifted from a tool to develop intelligent and creative abilities to a dangerous tool that manipulates the minds of adolescents and pushes them towards violence automatically to the stage of suicide, these games have produced a generation of adolescents practicing the most extreme types of violence in our contemporary history, and a study (Othman, 2018) confirmed that the negative effects of playing electronic games are numerous in terms of their role in school violence accidents of all kinds, as well as children's addiction to these games and associated problems such as vision and hearing problems, and given the views of parents, the results showed that parents face real suffering as a result of children's playing night electronic games, which affects their educational achievement, as well as the acquisition of the time and minds of their children, causing several problems within families, such as poor family communication between family members.

The "Joan 2016" study, which aimed to identify the possible effects of electronic games on children's intelligence and emotional development, confirmed the negative effects on children's intelligence and thinking development monitored where the electron games lead to the fact that children's thinking was characterized by extreme superficiality rather than deep thinking, as it negatively affects the personal and social relationships of children and causes children to be isolated and introverted. Also, the study (Fletcher 2015) showed the challenges in the use of digital games (computer) and its negative effects on children's addiction to these games, these effects include psychological diseases such as sleep disorder, anxiety, stress, depression, social isolation, introversion and individuality, isolation of the child him/herself from family and life, eye diseases, impaired vision, blurred vision, pain and tears in the eyes, poor educational attainment, the emergence of negative behaviors such as violence, cruelty, beating of young brothers, lack of adherence to communication, guidance and advice and being rebellious as well. The study (Anne \& Barbara 2015) showed the negative effects of online games, the study drew attention to the fact that some online players have died due to excessive play for long periods, in addition to the most common physical and psychological negative effects such as social isolation, the observed violence that manifests on their behaviors in life situations, muscle stress, visual impairment and weight gain, as well as the negative impact on academic and school achievement. While (Divan 2012) aimed to identify the effect of cell phones on children's behavioral problems, the results of the study showed that children using cell phones are more likely to develop behavioral problems such as mood swings, mental disorders, confusion and others compared to non-users of cellular devices, as these problems increase as the child uses cellular devices at an early age, while the study (Mohammed 2010) aimed to identify social problems by primary school children practicing electronic entertainment games. That study found that the games of 
entertainment have reduced the chances of students sitting with their parents because of their time playing electronic amusement games, the student's ability to see has been weakened after the addiction to electronic entertainment games, and the student felt pain in the back from sitting in front of the computer.

It is clear from the above that the overuse of electronic games in smart devices contributes significantly to the occurrence of many problems and hence the researcher has developed an interest in studying and identifying the nature of problems that result from excessive use of electronic games, where the study aims to determine the nature of problems (health, family, study and behavior) resulting from the excessive use of electronic games by children as well as to identify problems over the effects of electronic games and some variables attributable to (age, type, period of use of games, type of games). The ultimate goal of the study is to reach scientific and practical recommendations and proposals to reduce the problems of children's overuse of electronic games with smart devices.

\section{METHODOLOGY}

The study used the social survey method in the sample style, which consisted of (312) parents, where the questionnaire was distributed electronically to websites and groups that include parents of primary school students, the researcher obtained the approval of the majority of the sites' admins to conduct the research and distribute the questionnaire to the members of the electronic groups and gatherings who agreed to participate in the study. The researcher asked respondents to answer accurately and objectively during the time period 22/4/2020 to 21/5/2020. The researcher assured respondents that the research data is used for academic scientific research purposes and will remain confidential, moreover he explained to them that their participation in the research is voluntary and the possibility of withdrawing from participation is open at all stages before, during and after the actual participation. The researcher also assured respondents that there will be no financial cost incurred to them. The objectives, methodology, questions and purposes of the research were clarified along with the fact that the participation was an opportunity to exchange opinions and work to reduce the problems arising from the overuse of electronic games by children and exchange of recommendations with them and with the relevant authorities.

The researcher designed a questionnaire to measure the extent of the problems of children's overuse of electronic games in light of the social and psychological theoretical framework. and asked the researchers to answer the nature of the problems in four areas, each area contains 6 basic phrases and the questionnaire contains five items on demographic data on children, and thus the total paragraphs of the questionnaire (29) words, including demographic terms the type of child, year and place of residence, the number of hours of play, type of games used.

The researcher asked the respondents to answer the nature of the problems in four areas, each area contains 6 basic phrases and the questionnaire contains five items on demographic data on children, bringing the total paragraphs of the questionnaire to (29) phrases, including demographic terms, sex of child, age, place of residence, the number of hours of play, the type of games used.

The level of each dimension of the scale (weak, medium, high) was measured by subtracting the minimum degree from the upper limit (3-1=2) and then dividing this range by the number of cells of the three responses $(2 \leq 3=0.66)$ and then adding a minimum score to determine the effectiveness, dimension or scale of the phrase as follows:

The arithmetic average from (1 to 1.66) is weak, the arithmetic average from (1.67 to 2.33) average problems, the arithmetic average from (2.34 to 3$)$ high problems.

The validity of the tool was tested by presenting it to a number of academic arbitrators, all of whom confirmed that it is suitable for study. Pearson and the Alpha CrewNebach correlation coefficients were used to measure the validity and stability of the questionnaire, which reached $(84 \%)$ which is a high percentage of validity of the questionnaire. The researcher also used statistical coefficients of repetitions, percentages, weighted average, standard deviation and (One Way Nova) test for independent samples and a test to find out the differences between variables. Then the researcher analyzed the data using the Statistical Package for Social Sciences "SPSS" and extracted the results. 


\section{FINDINGS AND DISCUSSION}

\subsection{Respondents' demographic data:}

Table (1) Distribution of respondents by Gender, Age, Place of Residence, Duration and Type of Electronic Games used by children

\begin{tabular}{|c|c|c|c|c|c|c|c|}
\hline \multicolumn{2}{|c|}{ Variables } & \multirow{2}{*}{$\begin{array}{c}\begin{array}{c}\text { Frequ } \\
\text { ency }\end{array} \\
215\end{array}$} & \multirow{2}{*}{$\begin{array}{c}\% \\
68.9\end{array}$} & \multicolumn{2}{|r|}{ Variables } & \multirow{2}{*}{$\begin{array}{c}\text { Frequ } \\
\text { ency }\end{array}$} & \multirow{2}{*}{$\begin{array}{c}\% \\
16.0\end{array}$} \\
\hline Gender & Male & & & \multirow{5}{*}{$\begin{array}{l}\text { Place of } \\
\text { residence }\end{array}$} & Gaza north & & \\
\hline & Female & 97 & 31.1 & & Gaza & 181 & 58.0 \\
\hline \multirow[t]{3}{*}{ Age } & 4- 6 years & 83 & 26.6 & & Middle zone & 39 & 12.5 \\
\hline & $6-9$ years & 116 & 37.2 & & Khan Younis & 29 & 9.3 \\
\hline & $9-12$ years & 113 & 36.2 & & Rafah & 13 & 4.2 \\
\hline \multirow{4}{*}{$\begin{array}{c}\text { Duration } \\
\text { of playing } \\
\text { electronic } \\
\text { games }\end{array}$} & Less than 1 hour & 42 & 13.5 & \multirow{4}{*}{$\begin{array}{l}\text { Type of } \\
\text { games }\end{array}$} & Action and combat Games & 24 & 18.8 \\
\hline & 1 to 3 hours. & 118 & 37.8 & & Adventure Games & 30 & 23.4 \\
\hline & 3 to 6 hours & 101 & 32.4 & & Car games and racing & 74 & 57.8 \\
\hline & $6+$ hours & 51 & 16.3 & & Games Of Intelligence & 10 & 7.8 \\
\hline
\end{tabular}

Data analysis shows that $68.9 \%$ of the research sample are males and that (31.1\%) are female. It also shows that $37.2 \%$ of children are aged 6-9 years and (36.2\%) are aged 9-12 years old, and children aged 4-6 years (26.6\%). As for the place of residence for the child, the results showed that most of the children live in Gaza City by 58\% and then those living in northern Gaza (\%16.0), Middle zone Governorate (12.5\%) and Khan Younis (\%9.3) finally living in Rafah governorate by (\%4.2). As for the time spent by the child on electronic games, the maximum duration was (1 hour to less 3 hours) by (\%37.8) and then from (3 to less than 6 hours) by (\%32.4) Then (6 hours and more) by (\%16.3) and less than an hour by (\%13.5). As for the type of games played by children, the results showed car games and racing are the most important games by (\%57.8) then adventure games by (\%23.4) and then action and combat games by (\%18.8) and finally games of intelligence by $(7.8 \%)$

\section{2: Identifying the problems of overuse of children of electronic games on smart devices:}

The main objective of the study was to identify the problems resulting from the overuse of electronic games by children on smart devices where the results showed that there are different levels of problems as determined by the parents of children as shown above.

Table (2): illustrates the health problems caused by children's overuse of electronic games with smart devices

\begin{tabular}{|c|c|c|c|c|c|c|c|c|c|c|}
\hline Article \# & $\begin{array}{l}\text { Health problems in child's } \\
\text { overuse electronic games }\end{array}$ & & $\stackrel{\theta}{\check{\nu}}$ & 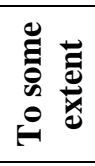 & $\stackrel{0}{Z}$ & 矛 & 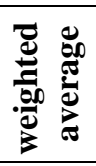 & 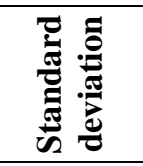 & 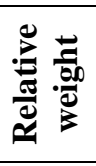 & 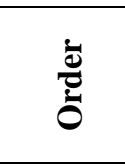 \\
\hline \multirow{2}{*}{1} & \multirow{2}{*}{$\begin{array}{c}\text { My child's ability to } \\
\text { concentrate has decreased. }\end{array}$} & Percent & 116 & 107 & 89 & \multirow{2}{*}{651} & \multirow{2}{*}{2.08} & \multirow{2}{*}{0.80725} & \multirow{2}{*}{69.3} & \multirow{2}{*}{2} \\
\hline & & $\%$ & 37.2 & 34.3 & 28.5 & & & & & \\
\hline \multirow[b]{2}{*}{2} & \multirow{2}{*}{$\begin{array}{l}\text { Electronic games reduced } \\
\text { my child's visual and } \\
\text { auditory abilities visual } \\
\text { and auditory abilities } \\
\end{array}$} & Percent & 99 & 74 & 139 & \multirow[b]{2}{*}{584} & \multirow[b]{2}{*}{1.87} & \multirow[b]{2}{*}{0.86532} & \multirow[b]{2}{*}{62.3} & \multirow[b]{2}{*}{5} \\
\hline & & $\%$ & 31.7 & 23.7 & 44.6 & & & & & \\
\hline \multirow{2}{*}{3} & \multirow{2}{*}{$\begin{array}{l}\text { My child's electronic toys } \\
\text { cause pain in the hands } \\
\text { and neck }\end{array}$} & Percent & 124 & 64 & 124 & \multirow{2}{*}{624} & \multirow{2}{*}{2} & \multirow{2}{*}{0.89299} & \multirow{2}{*}{66.6} & \multirow{2}{*}{3} \\
\hline & & $\%$ & 39.7 & 20.5 & 39.7 & & & & & \\
\hline \multirow{2}{*}{4} & \multirow{2}{*}{$\begin{array}{c}\text { I sleep a few hours as I use } \\
\text { a lot of games }\end{array}$} & Percent & 155 & 66 & 91 & \multirow{2}{*}{688} & \multirow{2}{*}{2.20} & \multirow{2}{*}{0.86532} & \multirow{2}{*}{73.3} & \multirow{2}{*}{1} \\
\hline & & $\%$ & 49.7 & 21.2 & 29.2 & & & & & \\
\hline \multirow[b]{2}{*}{5} & \multirow{2}{*}{$\begin{array}{c}\text { He suffered a general } \\
\text { weakness due to non- } \\
\text { handling of duties during } \\
\text { play }\end{array}$} & Percent & 119 & 73 & 120 & \multirow[b]{2}{*}{623} & \multirow[b]{2}{*}{1.99} & \multirow[b]{2}{*}{0.87663} & \multirow[b]{2}{*}{66.3} & \multirow[b]{2}{*}{4} \\
\hline & & $\%$ & 38.1 & 23.4 & 38.5 & & & & & \\
\hline \multirow{2}{*}{6} & \multirow{2}{*}{$\begin{array}{c}\text { Feeling constantly dizzy } \\
\text { and headache }\end{array}$} & Percent & 106 & 53 & 153 & 577 & 184 & 000 & 612 & 6 \\
\hline & & $\%$ & 34.0 & 17.0 & 49.0 & 311 & 1.84 & 0.90002 & 01.3 & 0 \\
\hline & Overall sc & & & & & 624.5 & 1.99 & ----- & 66.5 & Medium \\
\hline
\end{tabular}


Weighted average for health problems as determined by parents (1.99) with a relative weight (66.5) and this is an average level, the researcher explains this finding that excessive use on electronic games contributes very significantly to the reduction of the child's sleep hours and the decrease of the child's ability to concentrate and distracts the child's his and focuses his/her thinking on games. It also causes the child physical pain in the hands and neck and pain in the eyes and weakness in his visual and auditory abilities. These results are consistent with the results of the study (Fletcher 2015), Muhammad's study (2010) who confirmed in the results of their study on overuse of electronic games causes health problems for children such as muscle stress, back and neck pain, impaired vision, weight gain and simple superficial thinking.

Table (3): Explains the study problems caused by children's overuse of electronic games with smart devices

\begin{tabular}{|c|c|c|c|c|c|c|c|c|c|c|}
\hline $\begin{array}{c}\text { Article } \\
\quad \#\end{array}$ & $\begin{array}{l}\text { Study problems } \\
\text { resulting from the } \\
\text { child's overuse of } \\
\text { electronic games }\end{array}$ & & $\stackrel{\Xi}{二}$ & 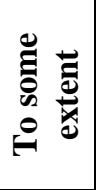 & $\stackrel{0}{Z}$ & 营 & 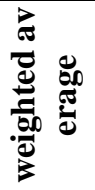 & 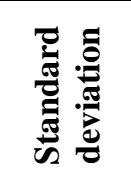 & 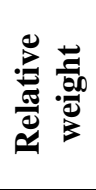 & $\stackrel{\grave{0}}{0}$ \\
\hline \multirow{2}{*}{1} & \multirow{2}{*}{$\begin{array}{c}\text { His level of education } \\
\text { has decreased } \\
\text { significantly }\end{array}$} & Percent & 116 & 72 & 124 & \multirow{2}{*}{616} & \multirow{2}{*}{1.97} & \multirow{2}{*}{0.87809} & \multirow{2}{*}{65.6} & \multirow{2}{*}{4} \\
\hline & & $\%$ & 37.2 & 23.1 & 39.7 & & & & & \\
\hline \multirow{2}{*}{2} & \multirow{2}{*}{ Neglects his homework. } & Percent & 118 & 96 & 98 & \multirow{2}{*}{644} & \multirow{2}{*}{2.06} & \multirow{2}{*}{0.83091} & \multirow{2}{*}{68.6} & \multirow{2}{*}{3} \\
\hline & & $\%$ & 37.8 & 30.8 & 31.4 & & & & & \\
\hline \multirow{2}{*}{3} & \multirow{2}{*}{$\begin{array}{c}\text { The games have lost him } \\
\text { the ability to } \\
\text { concentrate on studying. }\end{array}$} & Percent & 132 & 88 & 92 & \multirow{2}{*}{664} & \multirow{2}{*}{2.12} & \multirow{2}{*}{0.83891} & \multirow{2}{*}{70.6} & \multirow{2}{*}{1} \\
\hline & & $\%$ & 42.3 & 28.2 & 29.5 & & & & & \\
\hline \multirow[b]{2}{*}{4} & \multirow{2}{*}{$\begin{array}{l}\text { He doesn't have time to } \\
\text { study. }\end{array}$} & Percent & 131 & 86 & 95 & \multirow[b]{2}{*}{660} & \multirow{2}{*}{2.11} & \multirow{2}{*}{0.84459} & \multirow{2}{*}{70.3} & \multirow[b]{2}{*}{2} \\
\hline & & $\%$ & 42.0 & 27.6 & 30.4 & & & & & \\
\hline \multirow{2}{*}{5} & \multirow{2}{*}{$\begin{array}{l}\text { He deals with his } \\
\text { classmates with intensity } \\
\text { and violence. }\end{array}$} & Percent & 107 & 53 & 152 & \multirow{2}{*}{579} & \multirow{2}{*}{1.85} & \multirow{2}{*}{0.90107} & \multirow{2}{*}{61.6} & \multirow{2}{*}{5} \\
\hline & & $\%$ & 34.3 & 17.0 & 48.7 & & & & & \\
\hline \multirow{2}{*}{6} & \multirow{2}{*}{$\begin{array}{l}\text { He's out of school } \\
\text { without an excuse. }\end{array}$} & Percent & 93 & 21 & 198 & 519 & 166 & 68 & 553 & 6 \\
\hline & & $\%$ & 29.8 & 6.7 & 63.5 & 519 & 1.00 & 008 & 55.3 & 0 \\
\hline & Overall s & ore & & & & 613.6 & 1.96 & ----- & 65.3 & Medium \\
\hline
\end{tabular}

Weighted average for study problems as determined by parents (\%1.96) by relative weight (66.3) this is an average level, the researcher explains this finding that excessive use of electronic games causes the child to neglect his homework as spend a very long time on games instead of studying, as he loses the ability to focus in the study because all his thinking is focused on Games, as well as contributing to the dispersion of his thinking and therefore a significant decrease in his educational level, and these results are consistent with the results of the study (Osman 2018) (Fletcher 2015) and (Divan 2012) who agreed that the addiction of electronic games causes In the low level of educational attainment of the child and the acquisition of games over the time and mind and the appearance of symptoms of mental spacing out and loss of concentration. 
Table (4): Explains the family problems caused by excessive electronic games as determined by parents

\begin{tabular}{|c|c|c|c|c|c|c|c|c|c|c|}
\hline $\begin{array}{c}\text { Article } \\
\quad \#\end{array}$ & $\begin{array}{l}\text { Family problems arising } \\
\text { from the child's overuse } \\
\text { games }\end{array}$ & & $\stackrel{y}{\partial}$ & 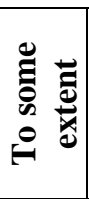 & 之 & 吾 & 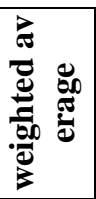 & 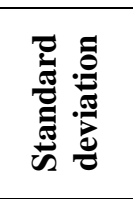 & 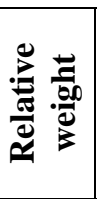 & 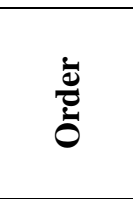 \\
\hline \multirow[t]{2}{*}{1} & \multirow{2}{*}{$\begin{array}{l}\text { His relations with his } \\
\text { family were weakened by } \\
\text { his isolation to play } \\
\text { electronic games. }\end{array}$} & Percent & 128 & 91 & 93 & \multirow[t]{2}{*}{659} & \multirow[t]{2}{*}{2.11} & \multirow[t]{2}{*}{0.83546} & \multirow[t]{2}{*}{70.3} & \multirow[t]{2}{*}{5} \\
\hline & & $\%$ & 41.0 & 29.2 & 29.8 & & & & & \\
\hline \multirow[b]{2}{*}{2} & \multirow{2}{*}{$\begin{array}{c}\text { Refuses to listen to } \\
\text { parental advice to reduce } \\
\text { the use of electronic } \\
\text { games }\end{array}$} & Percent & 161 & 98 & 53 & \multirow[b]{2}{*}{732} & \multirow[b]{2}{*}{2.34} & \multirow[b]{2}{*}{0.75359} & \multirow[b]{2}{*}{78} & \multirow[b]{2}{*}{2} \\
\hline & & $\%$ & 51.6 & 31.4 & 17.0 & & & & & \\
\hline \multirow[b]{2}{*}{3} & \multirow{2}{*}{$\begin{array}{l}\text { He fights a lot with his } \\
\text { brothers to get the device } \\
\text { where the game is on his } \\
\text { own. }\end{array}$} & Percent & 199 & 81 & 32 & \multirow[b]{2}{*}{791} & \multirow[b]{2}{*}{2.53} & \multirow[b]{2}{*}{0.67479} & \multirow[b]{2}{*}{84.3} & \multirow[b]{2}{*}{1} \\
\hline & & $\%$ & 63.8 & 26.0 & 10.3 & & & & & \\
\hline \multirow{2}{*}{4} & \multirow{2}{*}{$\begin{array}{l}\text { Playing the games } \\
\text { prevents him from doing } \\
\text { homework. }\end{array}$} & Percent & 151 & 98 & 63 & \multirow{2}{*}{712} & \multirow{2}{*}{2.28} & \multirow{2}{*}{0.77993} & \multirow{2}{*}{76} & \multirow{2}{*}{3} \\
\hline & & $\%$ & 48.4 & 31.4 & 20.2 & & & & & \\
\hline \multirow[b]{2}{*}{5} & \multirow{2}{*}{$\begin{array}{l}\text { His relationships with his } \\
\text { friends were weakened to } \\
\text { spend his time playing } \\
\text { games alone. }\end{array}$} & Percent & 123 & 97 & 92 & \multirow[b]{2}{*}{655} & \multirow[b]{2}{*}{2.09} & \multirow[b]{2}{*}{0.82548} & \multirow[b]{2}{*}{69.6} & \multirow[b]{2}{*}{6} \\
\hline & & $\%$ & 39.4 & 31.1 & 29.5 & & & & & \\
\hline \multirow{2}{*}{6} & \multirow{2}{*}{$\begin{array}{l}\text { He prefers electronic } \\
\text { games than going out } \\
\text { with his family. }\end{array}$} & Percent & 149 & 61 & 102 & 671 & 215 & 088561 & 716 & 4 \\
\hline & & $\%$ & 47.8 & 19.6 & 32.7 & $6 / 1$ & 2.15 & 0.88561 & 11.0 & 4 \\
\hline & Overall sc & & & & & 703.3 & 2.25 & ------ & 74.9 & Medium \\
\hline
\end{tabular}

Weighted average for family problems as determined by the parents (2.25) by relative weight (74.9) and this is an average level. The researcher explains this result that excessive electronic games works to create family problems represented in the quarrel between the child and his siblings to single out the device on which the games, and weakness of the child's relations with his family because of his preoccupation with games and thus his refusal to listen to the advice of his parents to reduce the use of games as the games keep the child from participating in homework. This result is consistent with the results of the study (Fletcher 2015) and (Osman 2018) who confirmed the overuse of games contributes to several family problems for the child which include poor communication between family members, quarrels between siblings, lack of counseling, disobedience, loss of communication with others and social isolation. 
Table (5): Explains the behavioral problems caused by children's overuse of electronic games as identified by parents

\begin{tabular}{|c|c|c|c|c|c|c|c|c|c|c|}
\hline $\begin{array}{l}\text { Article } \\
\quad \#\end{array}$ & $\begin{array}{c}\text { What are the } \\
\text { behavioral problems } \\
\text { caused by the child's } \\
\text { excessive use of }\end{array}$ & & $\stackrel{y}{\nu}$ & 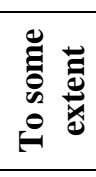 & Z & 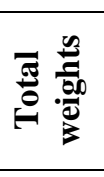 & 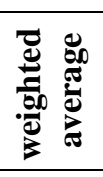 & 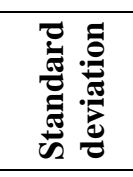 & 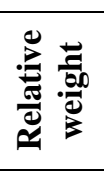 & $\stackrel{\dot{\tilde{g}}}{0}$ \\
\hline \multirow[b]{2}{*}{1} & \multirow{2}{*}{$\begin{array}{c}\text { Rapid nervous } \\
\text { agitation has become } \\
\text { a characteristic of } \\
\text { my child. }\end{array}$} & Percent & 161 & 90 & 61 & \multirow[b]{2}{*}{724} & \multirow[b]{2}{*}{2.32} & \multirow[b]{2}{*}{0.78152} & \multirow[b]{2}{*}{77.3} & \multirow[b]{2}{*}{3} \\
\hline & & $\%$ & 51.6 & 28.8 & 19.6 & & & & & \\
\hline \multirow[b]{2}{*}{2} & \multirow[b]{2}{*}{$\begin{array}{c}\text { Says some } \\
\text { inappropriate words } \\
\text { he learnt from the } \\
\text { online games }\end{array}$} & Percent & 119 & 64 & 129 & \multirow[b]{2}{*}{614} & \multirow[b]{2}{*}{1.96} & \multirow[b]{2}{*}{0.89241} & \multirow[b]{2}{*}{65.3} & \multirow[b]{2}{*}{5} \\
\hline & & $\%$ & 38.1 & 20.5 & 41.3 & & & & & \\
\hline \multirow[b]{2}{*}{3} & \multirow{2}{*}{$\begin{array}{c}\text { Imitates what he } \\
\text { learns from games } \\
\text { automatically at } \\
\text { home }\end{array}$} & Percent & 154 & 115 & 43 & \multirow[b]{2}{*}{735} & \multirow[b]{2}{*}{2.35} & \multirow[b]{2}{*}{0.71166} & \multirow[b]{2}{*}{78.3} & \multirow[b]{2}{*}{1} \\
\hline & & $\%$ & 49.4 & 36.9 & 13.8 & & & & & \\
\hline \multirow{2}{*}{4} & \multirow{2}{*}{$\begin{array}{l}\text { His behavior became } \\
\text { clearly aggressive. }\end{array}$} & Percent & 128 & 79 & 105 & \multirow{2}{*}{647} & \multirow{2}{*}{2.07} & \multirow{2}{*}{0.86241} & \multirow{2}{*}{69} & \multirow{2}{*}{4} \\
\hline & & $\%$ & 41.0 & 25.3 & 33.7 & & & & & \\
\hline \multirow[b]{2}{*}{5} & \multirow{2}{*}{$\begin{array}{c}\text { He's attached } \\
\text { electronic games } \\
\text { more than anything } \\
\text { else. }\end{array}$} & Percent & 163 & 87 & 62 & \multirow[b]{2}{*}{725} & \multirow[b]{2}{*}{2.32} & \multirow[b]{2}{*}{0.78635} & \multirow[b]{2}{*}{77.3} & \multirow[b]{2}{*}{2} \\
\hline & & $\%$ & 52.2 & 27.9 & 19.9 & & & & & \\
\hline \multicolumn{6}{|c|}{ Overall score } & 689 & 2.20 & ----- & 73.4 & Medium \\
\hline
\end{tabular}

Weighted average for behavioral problems, as determined by parents (2020) by relative weight (73.4) this is an average level and the researcher explains this result that electronic games contribute to the child's imitation of all that he learns from games automatically and the child is attached to games more than anything else, his emotions become nervous, fast, and his behaviors become more violent and aggressive. This result is consistent with the results of the study (Divan 2012), (Fletcher 2015) and (Tayor 2018) who confirmed that electronic games drive children automatically to violence and the emergence of negative behaviors such as violence, cruelty, changing mood, dullness and a sense of social isolation.

The results also showed statistically significant substantial differences in the problems of overuse of children on electronic games attributable to the variable of type and the differences in favor of the males. period of 3-6 hours, and the differences in favor of the period of 3-6 hours, and the existence of substantial differences statistically significant in the problems of excessive children on electronic games due to the change in the time period of playing electronic games and the differences in favor of the duration of 3-6 hours, as the results showed the presence of Substantial and statistically significant differences in the problems of over-child ing on electronic games are due to the change in the type of games and the differences were in favor of adventure games and combat. There are also statistically significant substantial differences in the problems of overuse of electronic games attributable to the age variable and the differences were in favor of the 9-12 year old group. Then, there are substantial and statistically significant differences in the problems of over-use of electronic games due to the variable of the time period of playing electronic games and the differences in favor of the duration of 3 6 hours. The results also showed that there were substantial differences of statistical significance in the problems of children's overuse of electronic games due to the variable of the type of games and the differences were in favor of adventure games and combat.

\section{CONCLUSION AND RECOMMENDATIONS}

The current study sought to identify the problems arising from the overuse of children on electronic games in smart devices from the parents' perspective. The study found problems resulting from that overuse where family problems came first and then behavioral problems and then health problems and finally study problems. The level of all these problems was (average) as the study found statistically indicative differences due to variable of type and age and the duration of games 
and type of games used. Through the results of the study the researcher recommends scientific recommendations to reduce problems with children's overuse of electronic games with smart devices, the recommendations as follows:

- Awareness of parents about the danger of some electronic games and the danger of spending a long time in front of electronic games on the child's physical, psychological and social health.

- Choosing the games suitable for the age and sex of the child and be free of any content that violates their religion and physical, emotional and psychological health.

- The family should set a specific period of time for children to use recreational electronic games, which should not exceed an hour a day as much as possible, and allow children to play physical and motor games away from sitting in front of contemporary technological means.

- Parents should not allow the child to play electronic games until after completing homework and eating daily meals.

- Strengthening the role of parents and guiding them to the care of children, identifying their problems and needs, building bridges of communication and encouraging them to communicate with family through dialogue, constructive discussion and modifying abnormal behavior through good examples and advice.

- Providing sports, scientific, cultural and social activities by the family to children so that they can invest their time.

- Constantly discussing what children are watching or playing and providing them with information and knowledge that makes them deal positively with what they see or play and entertain through.

\section{FUNDING}

The researcher has not received any financial support for research/authorship/ or publication of this article.

\section{REFERENCES}

- Abdul Sayed, M. (2019) A Safe education program to develop technological awareness of the dangers of e-games among kindergarten children. Journal of Studies in Childhood and Education, University of Assiut, Egypt, (9), p. 49.

- Abdulaziz, F. (2011), Risks arising from electronic games practiced by kindergarten children and methods of prevention, Journal of the Faculty of Education, Tanta University Faculty of Education, Egypt, (43), p. 604.

- Anne, M. (2015): Consequences of Play: A Systematic Review of the Effects of Online Gaming, International Journal of Mental Health and Addiction, v10 n1 p3-23

- Attia, S.A., (2019) A mentoring program for a sample of parents of children in kindergarten to raise awareness of the effects of electronic games on their children's behavior. Journal of Childhood Studies, Ain Shams University, Egypt, 22(8), p. 3.

- Dabbous, M.(2018). Behavioral problems due to the use of smartphones and their relationship to family communication from the point of view of parents among students of basic schools in Nablus governorate in Palestine, International Conference: Family Disintegration - Reasons and Solutions Gil Center for Scientific Research Tripoli.

- Divan HA, Kheifets L, Obel C, Olsen J. (2012). Cell phone use and behavioral problems in young children. J Epidemiol Community Health, 66(6), 524-9

- Elias, al-Tawer. (2018). Electronic games from creativity and innovation to a tool for suicide, Ministry of Higher Education and Scientific Research, Tunisia.

- Fletcher, J.(2015). Digital Games as Educational Technology: Promise and Challenges in the Use of Games to Teach, Educational Technology, v55 n5 p3-12.

- Hamshari, Omar. (2019). The addiction to the use of smartphones by students of Zarqa University and its negative effects on them from their perspective, Journal of Educational Science Studies, University of Jordan, Jordan, (46), p. 309.

- Ibn al-Hadalq, A., (2013) The advantages and disadvantages of electronic games and the reasons for their practice from the point of view of students of public education in Riyadh, Reading and Knowledge Magazine, Ain Shams University, Faculty of Education, Egypt, (138), p.158.

- Ibrahim, M. (2010). Social problems associated with the addiction to e-amusement games among primary school students (unpublished master's thesis) Helwan University, Egypt.

- Ibrahim, R. (2019). The use of educational electronic games via smartphone and its impact on the development of educational achievement and the love of cognitive polling in kindergarten stage high and low level of mental capacity. Journal of Arab Studies in Education and Psychology, Association of Arab Educators, (115) p. 53.

- Jafar, p. (2017) The impact of smart devices on family upbringing, Journal of Social Change, Mohamed Khudair Biskra University, Algeria, (2) p. 162. 
- Joan,F.(2016). Possible Effects of Electronic Social Media on Gifted and Talented Children's Intelligence and Emotional Development, Gifted Education International, v32 n2 p165-172.

- Metwally, M. (2017). The impact of touchscreen games on children's activities and development in early childhood, 3rd International Conference: Faculty of Education University 6 October Volume 5

- Moawad, R. (2016). The impact of playing with tablet games on the problem solving skills of preschool children, Educational Journal, Kuwait University, 31 (121), p.213.

- Mohammed, A., (2019) Proposed mechanisms to enhance the competitiveness of the educational media industry to address the dangers of children's addiction to globalized recreational electronic games, Scientific Journal Of The Sciences Of Physical Education And Sports, Mansoura University, Faculty of Sports Education, Egypt.(34),

- Othman, A. (2018). The impact of electronic games on the behaviors of children of the upper primary school, Journal of the Faculty of Education, University of Assiut, Faculty of Education, Egypt,34(1). 